\title{
PROPERLY SEXED, PROPERLY REPRODUCTIVE: SEXUAL AND REPRODUCTIVE RIGHTS AND THE RHETORIC OF THE NEW BRAZILIAN CONSERVATISM
}

\author{
DEVIDAMENTE SEXUADO, DEVIDAMENTE REPRODUTIVO: \\ DIREITOS SEXUAIS E REPRODUTIVOS E A RETÓRICA \\ DO NOVO CONSERVADORISMO BRASILEIRO
}

\begin{abstract}
Brazilian congressional membership has increasingly been marked by socially and economically conservative, often explicitly Christian, politicians. This study aims to provide a mapping and a critique of these congressmen's discourses on issues pertaining to sexual and reproductive rights, by means of discursive analyses of Law proposals currently under consideration by Congress, as well as other secondary documents. This approach may prove to be useful in identifying the discursive articulation of ideas of nationhood, normative genders, sexualities, and kinship structures in Brazilian conservative rhetoric, providing a useful starting point for further contestation of attempts to halt social recognition of rights to people categorizable as sexually and socially "deviant". This rhetoric holds a strong appeal for the precarious subjects of neoliberalism, because they provide a link between a deontological conception of divine triangulation as the basis of meaning, and bodily normativity/ethical purity in the face of disastrous "modernization".
\end{abstract}

Keywords: Sexual and reproductive rights. Discourse analysis. Religion.

\section{Resumo}

O legislativo brasileiro vem, cada vez mais, sendo dominado por parlamentares social e economicamente conservadores, com frequência explicitamente cristãos. Esses parlamentares são largamente devotos de denominações evangélicas, e vêm atuando mediante uma linguagem pretensamente constitucional, embora seus posicionamentos tendam a alinhar-se a sua doutrina religiosa. Este estudo pretende mapear, com fins críticos, os discursos desses representantes em questões relativas a direitos sexuais e reprodutivos. Para tanto, empregar-se-á o método da análise discursiva de Projetos de Lei sendo considerados pelo Congresso, assim como de outros documentos secundários. Essa abordagem pode ser útil em identificar a articulação discursiva de ideais nacionais, gêneros normativos, sexualidades e estruturas de filiação na retórica conservadora brasileira. Sugere-se que a retórica dos parlamentares religiosos detém grande apelo emocional aos sujeitos precários do neoliberalismo, por prover um elo entre concepções deontológico-teológicas da triangulação divina como significante-chave, bem como normatividade corporal/pureza ética face à "modernização".

Palavras-chave: Direitos sexuais e reprodutivos. Análise de discurso. Religião.

\footnotetext{
Anor Sganzerla

Professor do Programa de Pós-Graduação em Bioética da Pontifícia Universidade Católica do Paraná.

E-mail: anor.s@pucpr.br

Luiz Valle Junior

Mestrando em Relações Internacionais, Pontifícia Universidade Católica do Paraná.

E-mail: lacvjunior@gmail.com
} 


\section{Introduction}

Brazilian congressional membership has increasingly been marked by socially and economically conservative, often explicitly Christian, politicians. These are largely members of Evangelical religious denominations ${ }^{1}$, and have generally managed to coat their rhetoric in Constitutional trappings, however much of their usual discourse draws on religious doctrine (Biroli, 2016). This study aims to provide a mapping and a critique of these congressmen's discourses on issues pertaining to sexual and reproductive rights ${ }^{2}$, by means of discursive analyses of Law proposals currently under consideration by Congress, as well as other secondary documents. This approach may prove useful in identifying the discursive articulation of ideas of nationhood, normative genders, sexualities, and kinship structures in Brazilian conservative rhetoric, providing a useful starting point for further contestation of attempts to halt social recognition of rights to persons categorizable as sexually and socially "deviant".

In addition to the usual targets of conservative rhetoric, such as the LGBT population, Brazilian Congress' "Evangelical front" (their self-declared denomination, Bancada Evangélica) often presents arguments against groups generally under protection of those rights grouped around the umbrella term "sexual and reproductive rights", for example by attempting to punish individuals who disseminate information on abortion and who perform or facilitate abortion in any way, as well as advancing interpretations pertaining to the

1 That said, not all of those who oppose sexual and reproductive rights more generally have any explicit religious belief. A number of congressmen who oppose abortion and other related contentious issues make no recourse to religious arguments, and do not necessarily define themselves publicly as religious people (regarding the debate on abortion, see particularly Aldana, 2008; Luna, 2013; 2014). As Luna (2014) notes, though religious parliamentarians take the forefront of the assault on the right to abortion, non-religious ones are also divided on the issue, suggesting that religion is not the sole factor affecting parliamentary positioning.

2 As Xavier and Rosato (2016) explain, sexual and reproductive rights are separate but interrelated legal entitlements or demands for sexual autonomy (i.e. having sex with one's chosen partner according to one's own terms, without discrimination) and control over procreative possibilities (i.e. becoming a parent or not, and having the means and information to prevent or ensure childbearing). It is also worth noting that the authors' call for a more local intellectual engagement on issues of sexual and reproductive rights - or the denial thereof - is partially accounted for in the present article. moment of conception as the beginning of legal subject hood (thus entitling fetuses to an inviolable right to life), the proper structure of the familial entity (thus excluding homosexuals and other "alternative" familial structures). This has generally triggered backlash from feminist and other social movements who rightly perceive their rights to be under siege.

This study will thus proceed in three parts. The first section will attempt an analysis of the narrative structure of two prominent law proposals, the "Statute of the Unborn Child" [estatuto do nascituro, PL478/2007] and the "Family Statute" [estatuto da família, PL6583/2013] , recognized as strongly retrograde in issues of sexual and reproductive rights - particularly the right to safe abortion, pregnancy prophylaxis, and to same-gender marriage, cohabitation, and child-rearing. The second section will focus on the complicated intertwining of several discursive registers within these attempts to recover a supposedly lost ethos of moral and bodily purity. Among these registers, the most easily identifiable are likely to be those of nationhood, proper gendered embodiment and sexuality, moral purity (in the form of an ethics of religious asceticism), and an imperative to reproduction as well as an overvaluation of the idea of the unborn child as embodying the content of an absolute right to life. A cursory critique of feminist and queer praxis will also be attempted, in light of recent developments on Brazilian conservative narratives. Finally, some concluding remarks will be offered.

\section{The nation is just a big family}

The PL6583/2013 [Projeto de Lei, Law proposal], heretofore "Family Statute", sets off with a violent circumscription of legally valid kinship institutions; Art. 2 sets forth the concept of the "familial entity" as a "social nucleus formed by the union between a man and a woman, by means of marriage or stable partnership, or by a community formed by whichever parent and their descendants" (bold letters in the original, our translation). This prescription of a social-ontological primacy of the family - perhaps popularized by the canon of liberal

\footnotetext{
3 There are, of course, many more law proposals that could be designated for analysis. For a thorough, more quantitatively-inclined survey, see Luna (2014).
} 
writings, as well as its feminist critiques (see, particularly, Pateman, 1988) - is further reinforced by the ascription of rights to the familial entity qua social ontology. Art. 3 establishes that the state is obliged to "...assure to the familial entity the enjoyment of the right to health, to nourishment, to education, to culture, to sport, to leisure, to work, to citizenship and to community life" (our translation). In the section on justification, Anderson Ferreira, the congressman responsible for the proposal, further reminds us that " $[\mathrm{t}]$ he family is considered the first organized human group within a social system, functioning as a sort of basic unit of society" (our translation), such that this justifies concern over societal changes allegedly detrimental to the familial entity.

The conservative character of the proposition is also made manifest in the section on justifications. Ferreira states that alleged phenomena such as “... issues ranging from the grave epidemic of drugs [sic]... to domestic violence, teenage pregnancy, and even the deconstruction of the concept of the family, an aspect which haunts families and affects psychosocial individual dynamics" are detrimental to societal harmony, as "[a] balanced family, with valued self-esteem [sic] and assisted by the state is synonymous with a more fraternal and healthier society" (our translation). It would seem, then, that heterosexual and procreative impulses form the basis of societal wellbeing, with changes in these institutions representing a grave danger of social disintegration - here, figured as changing kinship arrangements, disharmonious relationships within the familial entity brought about by drug and alcohol abuse, etc.

The proposal also delineates a wide institutional network to provide assistance, care and information pertaining to familial entities, requiring mental health professionals, public defense attorneys, and other responsible public and private professionals to provide due attention to those families found to be under threat of "disunion", particularly when issues of drug or alcohol addiction are involved. The constant use of a language of danger (Art. 6, par. 2 and 3; Art. 7; Art. 9) strongly dramatizes the possible situations these restricted human groupings can face, treating them as monolithic entities capable not only of holding rights, but also of acting and being acted upon in "unison", as unitary social actors.
The narrative structure of the law proposal, read in conjunction with the overarching religious-conservative ideological background which supports it, pictures the family (as ideally structured around the fundamental mamanpapa-moi ${ }^{4}$ Oedipal structure, with those cases of "missing" parents being implicitly ascribed to unspecified disaster) as a homogeneous, trans-historical, social-ontological category, erecting it as a juridical entity entitled to being fostered by state and private agents. The section on justifications further figures the familial entity as being under siege by outside threats - with changing kinship structures, such as single parenting, LGBT parenting, childless couplings, etc., occupying a position equally disastrous to familial dissolution or discomfort brought about by teenage pregnancy, domestic violence, drug abuse, etc.

This heterosexist, bourgeois family ${ }^{5}$ model thus provides an idealized starting point and normative ideal which orients the entire proposal. Under this universalizing heterosexual presumption, even the material wellbeing of the familial entity is a "collective" good, in the sense that it matters little that its individual members be ascribed due amounts of whatever social goods the family might possess - the figure of the stay-at-home mother is thus implicitly condoned, with the issue of divorce being carefully elided so as to figure under the "threat come about by social change" rubric. The causal link drawn between societal wellbeing and familial wellbeing finally points to the intertwining of ideals of national development and social/moral purity, embodied by the properly gendered, properly monogamous, and properly reproductive heterosexual couple.

With these narrative strategies, the familial entity's relation to its perceived external threats ends up being one of conflict, strengthening and, presumptively, redemption.

4 On this terminology, see Deleuze \& Guattari, 1974. Traditional privatizing bourgeois psychoanalytic interpretations do provide an account that 1) privileges the bourgeois family-form (i.e. a private, cohabiting family, legally recognized via marriage, consisting of a man, a woman and their children) as being the bedrock of subjectivity; 2) refers the very possibility of psychic representation to paternal prohibition over maternal care (particularly after Freud's abandonment of the theory of seduction; see Laplanche, 1999); 3) normalizes genital sexuality as natural, implicitly privileging heterosexual, productive intercourse.

5 It is interesting to note that religious education and popular psychology are not entirely dissociated phenomena in the Brazilian context. Duarte and Carvalho (2005) note that the familial conception of many Evangelical religious denominations is eminently "psychologized", sometimes with explicit recourse to psychoanalytic conceptions of individual psychic formation within the family. 
The initial naturalness, the presumption of appropriateness and innocence of the family nucleus comes under siege by the "villain" of social anomie, and, through the law proposal, acquires the capacities needed to overcome its obstacles and restore its initial purity and wholeness. This process, of course, can only come about with the vilifying of whatever alternative familial structures figured as outside threats; therefore, the language of protection and exaltation of the familial entity (which, it bears reminding, is composed of a man, a woman and their presumptively biological children) requires and institutes the abjection of different kinship structures, including ones that might be perfectly heterosexual, but nonreproductive.

\section{Vessels and loving parasites}

Likely the most virulently anti-abortion law proposal under consideration by Brazil's Congress, the PL478/2007, or Statute of the Unborn Child, represents an attempt to confer rights upon unborn fetuses beginning at the moment of conception. Though Art. 3 explicitly recognizes that legal personality is contingent upon a live birth, the rights supposedly inherent upon the fetus are premised on its "human nature" (Art. 3), which, again, is recognized since conception. Art. 4 sets out a (somewhat comical) list of duties to be entertained toward the fetus, whereby, with "absolute priority", the "expectation of the right to life, health, nourishment, dignity, respect, liberty, family life [sic], as well as to safeguard it from all forms of negligence, discrimination, exploitation, violence, cruelty and oppression" (our translation). Regardless of the absurdity of conceiving of a fetus injured in its subjective dignity or in its due share in the social wellbeing of its collectivity, these duties are to be imposed upon public and private agents independently of extra-uterine life expectancy or any other form of morbidity. Fetuses conceived due to acts of sexual violence are also to be granted these rights, without "discrimination", and in those cases in which the rapist is identified, he will be responsible for providing a monthly allowance, therefore taking his “due” place in the fetus' extra-uterine life.

The proposal also establishes at least 1 year of detention in case of voluntary abortion, with technical expertise being an aggravating circumstance, and in case of making available or imparting knowledge on abortive methods. Penalties are also instated for "defamation" of the image of the unborn child (Art. 26), freezing, manipulating, or otherwise experimenting on the unborn child (Art. 25), exhibiting any images or representations damaging to the unborn child (Art. 27), among others. The granting of fundamental rights to unborn children seems to entail a new form of pseudo-juridical personality, in that the fetus is meant to be treated with due regard to its "peculiar condition as a future person in development" (Art. 6), as a full-fledged "member" of humanity, despite the dubiousness of its "claim" to being such.

Such attempts to curtail rights to abortion have generally been criticized along two fronts: first, that they deny women the ethical competency to decide in issues so clearly pertaining to their own bodies and life choices, with the undertone that pregnancy and child rearing is a mainly, if not exclusively, female task, and that no woman should become a mother against her will. Second, that the fetus cannot be considered a human being until a certain stage of its intra-uterine development, mostly because of the relatively late development of the central nervous system (Luna, 2014). The strong reliance on the juridical aspects of the right to life, as well as the notion of "expectancy" of rights, however, appear to give the Statute some degree of imperviousness as regards these more typical objections - particularly, the defense of the fetus' right to life can take both an individualistic (the fetus is a future human endowed with rights) and a collectivistic (interrupting a potential life is morally indefensible) form. Furthermore, the section on justifications also attempts to present the proposal under the rubric of "development", comparing Brazilian legislation unfavorably to other conservative bills which tended to "safeguard" fetuses in both the USA and Italy, and under the rubric of "bioethics", with explicit contempt for medical advances that hinge upon the possibility of research on human embryos - another argument that spans both individualist and collectivist argumentative strata.

Taken together, these two propositions sketch a more or less complete picture of the conservative rhetoric on sexual and reproductive rights that has increasingly come to define Brazilian gender politics. The ambivalence of the recourse to fundamental rights (the fetus is entitled to individual rights; the family only holds them collectively and as a heterosexual, reproductive entity), the selective 
employment of a rhetoric of moral purity and national development, the implicit logic of appropriateness/ normativity of traditional kinship structures as well as gender and sexual identifications, and the right to life mobilized only to serve a reproductive imperative, are all prominent features of conservative, religious discourse. Both also narrativize a logic of threatening societal changes, come about by homosexuality, scientific developments, feminist movements, drug addiction, early pregnancy (somewhat hypocritically), etc., as opposed to a lost background of moral and ethical purity which requires regeneration in order for the national body (defined in analogy to the family) to regain its "wholeness". It bears mentioning that, expressed in terms of individualistic/ collectivist conceptions, the arguments presented are hardly classifiable. The fetus is simultaneously figured as bearing the potential to be an individual - and thus already an (indirect, so to speak) rights-bearer - and as embodying a divinely ordained right to life - an argument having more to do with collective ethical representations than with presumably secular conceptions of lawfulness and individuality.

\section{Giving birth to the country}

The link between kinship structure and national ideology is a well-established theoretical argument in psychoanalytic anti-authoritarian literature. Marcuse (1966) remarks that " $[t]$ he severe father, who... subdues the death instinct in the Oedipus conflict, enforces the first "communal" (social) relations" (p. 80), and, as societies diversify and become complex in the division of labor and the ascribing of sexual-political authority, "...as the father is multiplied, supplemented, and replaced by the authorities of society, as prohibitions and inhibitions spread... [grows] the need for reinforcing the sense of guilt" (p. 81). Within this repressive context, “...which enforces the equation between normal, socially useful, and good, the manifestations of pleasure for its own sake must appear as fleurs du mal" (p. 51). Likewise, Reich (1946) remarks that the authoritarian state ensures its capillarity with the reproduction of subservient individuals via the reinforced authority of father figures. Nationalist sentiment is thus figured as a reiteration of familial attachment, a process whereby the symbolic representation of the nation assumes a prominent role.

This imbrication of politics, nationhood, religious melodrama, and familial heterosexism in Brazil, made glaringly obvious by the explicit filiation of political representatives to religious bodies and parliamentary groups such as the Evangelical Front, serves as a forceful reminder that conservative imagery provides a strong locus of attachment for citizens to live out the cruel promise of a better future (Berlant, 2011). The continued support for lawmakers who propose such things as the Family Statute and the Statute of the Unborn Child seems symptomatic of a longing for a societal wholeness which can only ever be provisionally met via the persecution of alternative bodily, spiritual, and social practices. Berlant (1997) exposes this longing for absolute presence, noting that citizenship functions, in capitalist, neoliberal democracies, much like a dead metaphor: "[i]n the fantasy world of national culture, citizens aspire to dead identities - constitutional personhood in its public-sphere abstraction and suprahistoricity, reproductive heterosexuality in the zone of privacy" (p. 60). Her subsequent focus on the figure of the "little girl" as a site of condensation for both conservative governmental and radical feminist discourses, however, can only be applied in the Brazilian context in relation to - that is to say, in a subordinate position to, but coimplicated with - the fetus as the ultimate locus of the right to life and the family as the reproductive site of heteronormativity.

In the Statute of the Unborn Child, the fetus is figured as bearing an inextricable right to life, premised on its belonging to "humanity" and to its legitimate "expectation of bearing rights". The manner in which it was conceived bears no relation to the legitimacy of its belonging to humanity and its rights-bearing expectation - meaning that rapists are, whenever possible, enshrined with the pseudo-biological status of father, and the legal-economic link of a monthly allowance similar in form to those due by divorced fathers. Women, in this regard, are remarkably absent from the text, except insofar as they are mothers. They exist only to the extent in which they facilitate the coming into being of that transcendental, trans-historical category of the child - or of the fetus who bears a legitimate expectation to become a child. Paradoxically, then, the mother is figured both as absolute presence, insofar as she is the condition of 
being for the fetus, and absolute absence, in that her role in conception is merely that of a vessel, abstracted from concreteness. This figuration leads us to an image of a woman giving birth to the notion of humanity itself; delivering community, nation, and world - that is to say, the Child form - into the hands of the patriarchal family. This entails an immediate evacuation of the possibility of women having any relevant subjective existence which is not itself mandated by scripture and enforced by paternal law. Women's absolute presence/absence, then, revolves around their status as an object, one that is both indispensable and, taken individually, worthless. Their fleeting transcendence in delivering the Child is soon to be subsumed into the (implicit) immanence of caring for it and presumably fading out of view once that task is completed.

In this discourse, then, the Child is a sort of ultimate signifier; that which mediates between the masculine world of political authority and divine selfpresence, and the feminine pole of absent positivity - the paradox of the nothing that originates Being. The Child becomes a representational index of all possible sexual and political normativity, and futurity is inscribed within (hetero)sexual difference as the basis of community itself. Edelman (2004) similarly contends that " $[t]$ he Child... marks the fetishistic fixation of heteronormativity: an erotically charged investment in the rigid sameness of identity that is central to the compulsory narrative of reproductive futurism" (p. 21-2). Heteronormativity thus appears as the overarching scheme which enables this tripartite structure of political (re)generation: Man, as the divine manifestation of authority; Woman as the emptiness that enables that authority's self-presence; and Child as the ultimate drive to the future, metaphorically signifying the absolute of normative kinship and political structure, as well as the permanence and continuity of Being.

These subject-positions are all neatly disembodied and devoid of the vicissitudes of the drives. By analogy to the fixity and eternal character of religious Scriptures, the family-form and the nation-form attain transcendence from both history and the human predicament in general, figuring as timeless normative ideals that need only be recovered by purging society from its "filth". Berlant(1997) further notes, on the rhetorics of melodrama frequently used by conservatives: "[t]his sentimentality suggests how fully the alarm generated around identity politics... issues from a nostalgia or desire for a suprahistorical nationally secured personhood that does not look to acts of history or the body for its identifications" (p. 72). Fetus, family and nation are thus all expected to follow from the ontologically prior, divinely ordained triad of (a) sexual difference in the service of reproductive futurity. (A)sexual because, again paradoxically, there seems to be no bodily difference inscribed into these self-present, self-contradictory poles; the body here is vacated as a site for political action and rights-bearing, thus conveniently eliding the apparently absurd notion that a woman might not wish to carry a fetus conceived out of sexual violence, or even that anyone might derive pleasure from their bodies.

This is the discursive operation which allows such "societal changes" as a more general acceptance and open practice of homosexuality, or a refusal of mothering, to be figured as threats equivalent to drug addiction (another discursive point of congregation for classist, racist, homophobic rhetoric), teenage pregnancy, domestic violence, among others - while potentially impregnating sexual violence is essentially vacated as a criminal offence. One might note that this exposition seems remarkably close to the Lacanian scheme of sexual difference; men have, and women masquerade as, the phallus as the condition for Symbolic castration and entry into culture, all in the service of an inescapable desire identified with lack (Lacan, 1966). Doing away with sexual difference, however, supposes the severing of the admittedly discomforting link between the penis and the phallus, a severing diligently argued for by theorists such as Judith Butler (1990). That doing away, moreover, is paradoxically what Brazilian conservative discourse ends up doing. It does so by replacing the Real of phallic possession and mastery (what is sometimes termed the phallic mother) by the Real of reproductive futurity, identifying women's monopoly of procreative capacity, and men's socially ordained monopoly on political authority, as merely incidental for the reproduction of the divinely ordained Papa/Dieu-Maman/Néant-Moi/ Signifiant structure (Deleuze \& Guattari, 1972).

The basic narrative structure of this transcendental triangulation is figured as only then transposed into the societal arena, with the abjection of homosexuals, 
feminists, transgender people, etc. Further indication of this is the now almost incessant talk of banning "gender ideology" from school curricula (Biroli, 2016), in which ideology figures the Marxist notion of false interests in the service of other social groups' interests - and thus in opposition to one's "real" interests, which can, in this scheme, only be figured as being in service to reproductive futurity. This argumentative structure, it must be noted, only acquires this sort of coherence retrospectively, much like gender itself (Butler, 1990). That kind of insensitivity to history and corporeality - the discursive mobilization of an ahistorical "time immemorial" in which men and women gathered in marital bonds, not ever straying from strict reproductive monogamy and bourgeois privacy - allows conservative politicians to effectively sustain the discursive fiction of the life-embodying fetus without being phased by feminist or evidence-based public health arguments. It is the possibility of shifting between the transcendental triangulation of Dad/BeingMom/Nothingness-Me/Significance and their corporeal correlates within different discursive contexts that allows such flexibility and apparent cohesion to conservative opposition to sexual and reproductive rights. This narrative can only make room for "deviant" bodily uses if they are placed outside the normatively regulated sphere of potential recognition; thus, inclusion into this kind of discourse on the part of homosexuals, women who are sterile or choose not to procreate, transgender people, etc., can only ever be achieved as a permanent outside - hence, through abjection.

The law proposals under consideration here, though more or less self-contained documents, do reference wider political contexts from which they may draw legitimacy. The operation of figuring societal change as anomie draws continual support from powerful apparatuses that dictate the proper ways in which individual and collective bodies can exist. It is instructive that, as Mesquita and Perucchi (2016) argue, numerous religious leaders conflate popular psychological, pseudo-scientific arguments with biological and theological ones. Their analysis on homosexuality in religious discourse shows a number of operations to vilify improper bodily uses. Referring to homosexuality as the devil's doing, framing homosexuality as a behavioral category amenable to change rather than a locus of sexual and political identity, condemning non-reproductive use of genitalia (which are furthermore not "God's sexes", as one commentator put it, presumptively referring to the penis and the vagina), etc., are persuasive ways of delegitimating deviant uses of embodiment, thus mobilizing normative societal representations of normative propriety.

Thus biological and political continuity, moral purity, strict coherence between sexual assignment and gendered embodiment, all tied up around the imperative to reproduction, walk hand in hand in defining the core of conservative discourse pertaining to sexual and reproductive rights. These rights can then only ever figure negatively, because the "social body" must be put in service of the Child rather than individual and social wellbeing (categories so indissociably linked with reproduction and proper mores that they finally become tautological). Given the persistence of oppressive normative ideals within Brazilian society, particularly against women and the LGBT population, further discussion on queer and feminist praxis is in order, so that concerted opposition becomes able to tackle more efficiently the various uses of conservative rhetoric on sexual and reproductive rights.

\section{Feminist contentions, queer abjection}

Feminist scholars have long debated the ideological means by which women are posited as inferior to men and cast into a murky private sphere of family life and male authority. Pateman (1988), for instance, provides an elegant critique of contractualist writers who implicitly assume that an original sexual contract subordinating women via the marriage institution is sealed before the establishment of civil society by means of the social contract. This form of critique often relies on Wittig's (1990) contention that Aristotelian metaphysics privileges ontological unity rather than multiplicity, establishing binary hierarchical relations between terms such as one/ many, Greek/barbarian, man/woman in a relation of analogy to presence and absence, good and bad. As Halley (2006) puts it, feminism has at least three core characteristics, 1) the belief that society is somehow divided into two genders/sexes; 2) that men are hierarchically superior to women and 3) that women should (at least) be equal to men. This normative commitment to improving women's life chances through structural change, however, has 
given way to an incorporation of watered-down feminist agendas in several power-saturated institutions, such as the United Nations. What Halley terms governance feminism, then, is an institutionalized form of more radical theoretical approaches to feminist agendas, that relies on piecemeal legal and institutional improvements rather than oppositional politics. This incorporation of feminism into the halls of power vacates the critical potential of feminist praxis. In this vein, the author argues that a "break from feminism" is in order. Queer theoretical engagement may represent such a break.

Judith Butler's (1990) work on performativity is one of the most influential in what can retrospectively be termed queer theory. She argues that gender is not a monolithic identity immediately aligned with anatomical sex. No one, then, properly embodies "man" or "woman"; all identity can only ever be provisionally achieved through its iterability and citationality. In that sense, gender identity is performative, always constituting itself again and again through discursive acts which cite, iterate, normative structures, acquiring apparent cohesion only as an ex post facto formation. In that sense, sexual and gender normativity in modern, capitalist societies is generally assumed to be congruent with a heterosexual matrix; normative identity thus necessarily assumes that anatomical sex, gender identity and desire follow neatly from one another in a particular manner-ideally, producing heterosexual men with penises and heterosexual women with vaginas. Informed by psychoanalytic literature, she further argues that seemingly stable sexual and gender identities - man, woman, heterosexual, homosexual can only be the product of a melancholic renunciation of those aspects in one's potential identity that contradict one's "actual" identity. Therefore, being straight requires a renunciation of one's homosexual desire, just as an entirely homosexual object-orientation (in psychoanalytic terms) requires the renunciation of heterosexual impulses.

A typical objection to Butler's work is that wrong interpretations of it as a kind of "gender-astheatre" conception, in which the clothes one picks in the morning are as determinative of their gender identity in that particular moment than years of socialization under oppressive normative structures. Another is that she vacates the physicality of the body and subsumes any and all personal experience of corporality under the umbrella-term "discourse". Salamon (2010), however, reminds us that discursive approaches do not signal that gender identity is easily changeable or even disposable; they simply point to both the limits and the possibilities of the plasticity of gendered experience under societies as heavily normativized as late capitalist democracies. Normativity, then, figures as the main defining feature of the field of gender and sex. This term is generally understood to refer to clusters of more or less explicit social norms which govern individual actions by being inscribed within their bodies via psychic and disciplinary processes of subjectivation. This latter word, derived from Foucault's (1975) assujetissement, points at a productive conception of power. Rather than considering, with traditional political science approaches, that power as a category refers to prohibitive or coercive practices (say, the Weberian "B getting A to do what it would not otherwise do"), Foucault considers power as a productive strategic placement within an infinite web of hierarchical social relations. This productive character of power thus both enables and circumscribes the possibility of subjectivity; one only becomes a subject because of power, but one cannot endlessly expand or alters one's subjectivity because that power largely determines, through what we might call normativity, the possibilities that are open to any particular subject.

If Foucault's insights are accepted, this means that traditional, privatizing psychoanalytic paradigms need to be reconsidered in order to make sense of a social existence which is shot through with significance and power relations. Deleuze and Guattari's Anti-Oedipus (1972) provides one such account, treating desire as a productive category rather than one irrevocably circumscribed by lack. They criticize the traditional Lacanian split subject, arguing that the unconscious should be read more as a factory than a theatrical set up. If that is the case, then it might be said that the psychoanalytic unconscious, rather than being a result of primary refoulement, acts as the primordial motivator of socially inflected behavior. Social rules are introjected and in regulating the subject, allow her to become a subject, inverting the traditional liberal notion that individuals precede society. This view poses a significant challenge to much feminist scholarship, which relies largely on treating "woman" and "man" as sufficiently stable identities, often ones that bear a number 
of transhistorical traits, that enable concerted political action and opposition.

Queer theoretical approaches, however, rely on these insights to scrutinize the myriad ways in which normativity is historically constituted and politically deployed to form certain subjects rather than others. One particularly insightful Foucauldian notion is that power, aside from being productive, always presupposes resistance ${ }^{6}$. Norms are therefore never perfectly internalized, and their very deployment allows for particular desires and practices to be named and acted upon by non-docile subjects. This further allows for a critique of all oppressive normative clusters, including those that, from a liberal interest-group standpoint, would be left out of the equation, such as homonormativity the exclusionary practices of the LGBT "community" itself, predicated as it is on hypermasculinity and male dominance at the expense of non-normative gay men (that is to say, nonwhite, effeminate, "promiscuous", etc.), lesbians, and transgender people. As $\mathrm{Puar}^{7}$ (2007) states, "... access to capital - "market virility" mediates national belonging and the folding into life for multicultural ethnic subjects, homonormative subjects, and possibly even some of those subjects positioned at the intersection of the two" (p. 27).

If conservative rhetoric is so emotionally appealing and "sticky" - in Sarah Ahmed's terms (2014) -, new conceptual tools are required to mobilize an opposing discourse which can be equally convincing. Feminist critique has increasingly been normalized, making its way to top decision-making bodies; its appeal to a radical critique, then, has waned in face of its totalizing and essentializing tendencies. A queer critique of identity itself, and the supposedly totalizing place it has come to occupy in contemporary politics, may be productive in attempting to fight for sexual and reproductive rights. This paper proposes a return to bodily experience and

6 There is much debate around this conception. Here, Butler's (2013) insight that "resistance" signifies rather the inevitable failure of "perfect" norm-determined behavior than an explicit, intentional subverting of normative structures will be used.

7 Brazilian scholarship has also taken note of this phenomenon. Coitinho Filho (2015) argues that the discussion around the term "homoafetivo" (roughly translated, homoaffectionate), a proposed substitute for "homosexual", ends up entangling homosexual relations to the heterosexual familial model, erecting and legitimating new forms of normativity while depriving sexual deviance of critical potential. "concrete" (though by no means less burdened by the inevitable totalization of signification in psychic and "material" life) experience of those who are relegated to the margins of intelligible living.

\section{Saying the body}

The place of embodied phenomenology, then, must be recovered in feminist and queer praxis. As Salamon (2010) points out, however, this cannot be done in a simplistic pseudo-materialistic manner, as such efforts tend to reify gender binarisms even as they affirm the right of, say, transgendered and transsexual people to occupy a place of undecidability within the male/ female topography. One avenue to approach this issue is to focus on precarity and recognition, which provide a pathway to the body as always irrevocably in-relation (Butler, 2015). Undoubtedly, recognizing exclusively those bodies that are "proper" in terms of reproductive capacity and action, paradoxically desexualizing them, represents a violent circumscription of those identitary categories which cannot even partially conform to heterosexist futurist subject-positions, and which are discursively saturated points of inflexion of strategically deployed sexuality (Foucault, 1976). It is essential to note, however, that categorizing Brazilian conservative discourse as a purely modern manifestation of sexual regulation would be to miss the point of Foucault's agonistic approach to discursivity: while one general paradigm of regulation may generally succeed another, elements of the first are always kept by its successors. The discourse under consideration here, then, holds elements - particularly those more explicitly drawn from syncretic interpretations of Christian Scriptures which cannot be reduced to, say, the psychiatrization of gender and sexuality or any other single apparatus ${ }^{8}$.

Edelman (1994) reminds us that understanding sexuality - in broad Foucauldian terms, the saturated point of condensation for the numerous discursive practices around bodily normative imperatives and regulative strategies and apparatuses - requires the recognition that meaning by juxtaposition can only ever be simulated within a binary logic of presence/absence:

8 On this, see Butler's discussion of the Marriage pour touts debate in France (Butler, 2004). 
...sexuality cannot be identified with the metonymic without acknowledging that the very act of identification through which it is constituted as sexuality is already a positing of its meaning in terms of a metaphoric coherence and necessity - without acknowledging, in other words, that metonymy itself can only generate "meaning" in the context of a logocentric tradition that privileges metaphor as the name for the relationship of essence (p. 8).

Conservative rhetoric, as already noted, identifies deviance from the heterosexist reproductive imperative (metonymically identified with divine triangulation) with societal anomie more generally (drug abuse, domestic violence, teenage pregnancy, etc., analogously function here as general indexes of social decadence brought about by reckless modernizing of social relations). The figure of the homosexual (interestingly, male homosexuality seems to be a privileged locus for discursive abjection), or that of the non-reproductive heterosexual woman, thus come to metonymically figure the departure from the divinely ordained reproductive triad, a sort of original sin to which no true meaning can ever accrue. The heterosexual family form provides the support through which reproductive discourse can simultaneously disembody and reify an idealized notion of the "margarine family" while casting "deviants" into the realm of pure corporeality.

This form of denial of social recognition almost invariably leads to an increase in what Judith Butler terms precarity - a situation of uncertainty about the reproduction of one's life in subjectively dignified terms (Butler, 2015). She argues that the bodily claim to a respectable life cannot be reduced to its purely discursive constitution, or to predetermined, explicitly political, demands. The very signifying function of the body, and its public presentation, is a demand for dignity, a right to appear that is recognized only in its performance. Notions such as "the people" or "LGBTQ" or whatever other deceptively cohesive collective body therefore are constituted in the very act of appearance, and in the ways in which that appearance is made explicit by an apparently inexhaustible catalogue of technologies, sensory perceptions and signifying practices:

9 This is a common popular saying in Brazil, due largely to the portrayal of "perfect", white families in margarine commercials - all formed by man, woman and two children, one male, one female. [i]f the people are constituted through a complex interplay of performance, image, acoustics, and all the various technologies engaged in those productions, then "media" is not just reporting who the people claim to be... (Butler, 2015, p. 20)

This notion of the media, though conceived of primarily in the context of generalized popular protests in the early 2010s, may be applied to the present analysis in the sense that it privileges embodied presentation rather than some essence to which rights and recognition are supposed to accrue. It is not a mere accident that Butler argues that violence against a person who is identifiably a member of some group discursively construed as deviant is aimed both at the individual in question and at the group that person is metonymically signifying. An identifiable ethical and aesthetic relation to one's body thus enters the picture as the fundamental mediator between sensory apprehension, affective responses, and personal, bodily significations.

It would seem, then, that continued engagement towards resignifying spaces and generally attempting to make oneself appear to others is an intrinsically political endeavor, generating demands for dignity by the very act of assembly. This, however, runs the risk of falling into the identity trap, reifying an endless number of social categories meant to acquire recognition from the political community only insofar as they coherently embody that metaphorical presence (Brown, 1995). Mahmood's (2011) approach to this, from the standpoint of the structure/agency debate, is generally to point out that agency need not be explicitly political to represent a form of autonomy. Drawing on Foucault's notion of an esthétique de soi (FOUCAULT, 1984), she contends that pious, self-organizing religious women in Egypt exert a kind of agency uncontemplated by Western feminism's usual focus on confrontational, identity politics.

However, basing political agency on such attempts of ethical self-fashioning runs the risk of being complicit with neoliberal agendas, eventually dismantling the very possibility of concerted action against the damning effects of global capital and disciplinary apparatuses (such as that of sexuality) on people's lives. Berlant (2011) acutely recognizes this, basing a critique of the affective life of 
the neoliberal subject on the notion of cruel optimism, the attachment to certain socially available scenes which can only ever be met with failure to conform properly. The incessant struggle for survival and dignity, then, is figured as perhaps the most important determinant in people's political lives.

Perhaps the common denominator to all these approaches is the widespread but paradoxically underplayed phenomenology of embodiment (though Berlant's work already represents an important step towards bringing the body into focus). Basing political critique on the way precarity differentially affects certain kinds of bodies - black bodies, female bodies, queer bodies, poor, working bodies - presents both a promise of broad coalition-building and a danger of perpetual disunity. Further questioning of the politicalnormative praxis of feminist and queer movements thus cannot be isolated from a concerted critique and discussion of the differential effects of globalized capital and regulatory apparatuses - say, the statistical behemoth of UN agencies or the neoliberal agendapushers of the IMF and the WB, as well as conservative congressional fronts and social groups - over differently embodied groups of people in geographically and socially different regions of the world. Perhaps a return and a reworking to Foucault's intellectuel spécifique is in order for the Western Left to be able to rearticulate concerted opposition to the heightening of precarity brought about by eroding certainties and continual undermining of traditional ideals of nationhood and social normativity - erosions which are, as suggested here, often met with conservative backlash, threatening the very existence of non-white-male-bourgeois people.

Though obviously discourse-oriented, this approach brings with it at the very least a promise to bring the body back into focus, thus presenting a challenge to conservative rhetoric on sexual and reproductive rights and its onto-theological shield. It might be productive, then, to ground the struggle for bodily autonomy along the palpable, affectively charged categories of precarity, suffering and the search for happiness and ethical fulfillment.

\section{Conclusion}

It bears reminding that this essay necessarily has a rather narrow focus. Aspects such as the implicit racializing, classist and hypocritical entangling of conservative politicians, Evangelical churches and global capital in the shaping of political ideology in contemporary Brazil (and elsewhere) are unfortunately left out, but provide a promising avenue of inquiry for scholars preoccupied with the resurgence of conservative, xenophobic, sexist, racist, etc., rhetoric and normative ideals in the Western world.

It was suggested that this rhetoric holds a strong appeal for the precarious subjects of neoliberalism, struggling as they are with irreducible demands for survival and recognition, particularly because they provide a link between a deontological/theological conception of divine triangulation as the basis of meaning, and bodily normativity/ethical purity in the face of a demonized movement toward "modernization", equated with social anomie. Homosexuality, childless couplings, drug addiction, teenage pregnancy, rampant crime, poverty, etc., are thus figured as equivalents in the attempt to undermine core, traditional values which provide strong ethical and communal attachments to people whose only certainty in life is perceived to be the further eroding of traditional certainties.

In this context, a shifting commitment to theo-ontological and bodily registers of discursive deployment provides a striking flexibility to conservative rhetoric, ensuring its appeal in lieu of a demand for philosophical coherence. The complicated intertwining of this nearly eschatological narrative of a retrieval of moral purity faced with the modernizing end of times provides a strong affective locus for the cruel optimism of achieving the good life among infinitely fluid social, economic, and political contexts. Feminist and queer praxis thus needs to articulate a more secure grounding for coalition-building, at the risk of remaining atavistically engaged to ever-so-multiplying identity categories and atomistic engagement with minor issues unrelated to developments in the differential ascribing of precarity. 


\section{References}

AHMED, Sarah. (2014). The cultural politics of emotion. Edinburgh, United Kingdom: Edinburgh University Press.

ALDANA, Myriam.(2008). "Vozes católicas no Congresso Nacional: aborto, defesa da vida". Revista de estudos feministas, vol. 16, no 2. Available at http://www.scielo.br/ scielo.php?script $=$ sci_arttext\&pid $=$ S0104-026X2008000 $200018 \& \operatorname{lng}=$ en $\& n r m=$ iso, retrieved $29 / 03 / 2017$.

BERLANT, Lauren. (1997) The queen of America goes to Washington city... Durham, United States: Duke University Press.

BERLANT, Lauren. (2011). Cruel Optimism. Durham, United States: Duke University Press.

BIROLI, Flávia. Aborto em debate na Câmara dos Deputados. 2016. Available at http://redesaude.org.br/ comunica/wp-content/uploads/2016/10/Estudo-FlaviaBiroli-29-09-2016_def.pdf, retrieved 31/01/2017.

BROWN, Wendy. (1995) States of Injury: Power and freedom in late modernity. Princeton, United States: Princeton University Press.

BUTLER, Judith. (1990) Gender Trouble: feminism and the subversion of identity. New York, United States: Routledge.

BUTLER, Judith. (2004) "Is kinship always already heterosexual?" IN: BUTLER, Judith. Undoing gender. New York, United States: Routledge, pp. 102-131.

BUTLER, Judith. (2015). Notes toward a performative theory of assembly. Cambridge, United States: Harvard University Press.

COITINHO FILHO, Ricardo A. (2015). “O lugar do afeto na produção do 'homoafetivo': sobre aproximações ao familialismo e à aceitabilidade moral". Revista Ártemis, vol. $19, \mathrm{n}^{\circ} 1$, pp. 168-179.

DELEUZE, Gilles; GUATTARI, Félix. (1972). L'anti-

Edipe. Paris, France: Éditions de Minuit, 1972.
DUARTE, Luiz ; CARVALHO, Emilio. (2005) "Religião e psicanálise no Brasil contemporâneo". Revista de antropologia, vol. 48, $\mathrm{n}^{\mathrm{o}} 2$. Available at http://www. scielo.br/scielo.php?script $=$ sci_arttext\&pid $=$ S0034$77012005000200002 \& \operatorname{lng}=\mathrm{en} \& \mathrm{nrm}=\mathrm{iso} \# \mathrm{tx} 02$, retrieved $29 / 03 / 2017$.

EDELMAN, Lee. (1994) Homographesis: Essays in Gay literary and cultural theory. New York, United States: Routledge.

EDELMAN, Lee. (2004). No Future : Queer theory and the death drive. Durham, United States: Duke University Press, 2004.

FOUCAULT, Michel. (1984). "Une esthétique de l'existence“. IN : FOUCAULT, Michel. (1984) Dits et écrits, vol. 4. Available at http://1libertaire.free.fr/ MFoucault214.html, retrieved 11/08/2016.

FOUCAULT, Michel. (1975) Surveiller et punir. Paris, France: Gallimard.

FOUCAULT, Michel. (1976) Histoire de la sexualité I : la volonté de savoir. Paris, France: Gallimard.

HALLEY, JANET. (2006). Split decisions: how and why to take a break from feminism. USA: Princeton University Press, 2006.

LACAN, Jacques. (1966). "La signification du phallus". IN : LACAN, Jacques. Écrits. Paris, France: Seuil, 1966.

LAPLANCHE, Jean. (1999). Essays on otherness. New York, United States: Routledge, 1999.

LUNA, Naara. (2013) "O direito à vida no contexto do aborto e da pesquisa com células-tronco embrionárias". Religião e sociedade, vol. 33, no 1. Available at http:// www.scielo.br/scielo.php?script $=$ sci_arttext\&pid $=$ S0100$85872013000100005 \& \operatorname{lng}=\mathrm{en} \& \mathrm{nrm}=\mathrm{iso}, \quad$ retrieved 29/03/2017. 
LUNA, Naara. (2014). "Aborto no Congresso Nacional: o engrentamento de atores religiosos e feministas em um Estado laico". Revista Brasileira de Ciência Politica, $\mathrm{n}^{\circ}$ 14, pp. 83-109. Available at http://www.scielo.br/pdf/ rbcpol/n14/0103-3352-rbcpol-14-00083.pdf, retrieved 29/03/2017.

MAHMOOD, Saba. (2011). Politics of piety: the Islamic revival and the feminist subject. Princeton, United States: Princeton University Press, 2011.

MARCUSE, Herbert. (1966). Eros and Civilization. Boston, United States: The Beacon Press.

MESQUITA, Daniele; PERUCCHI, Juliana. (2016). "Não apenas em nome de Deus: discursos religiosos sobre homossexualidade". Psicologia e Sociologia, vol. 28, nº 1 . Available at http://www.scielo.br/scielo.php?script=sci arttext\&pid=S0102-71822016000100105\&lng=en\&nrm =iso, retrieved 29/03/2017.

PATEMAN, Carole. (1988). The Sexual Contract. Palo Alto, United States: Stanford University Press.

PUAR, Jasbir. (2007). Terrorist assemblages: homonationalism in queer times. Durham, United States: Duke University Press.

REICH, Wilhelm. (1946). The mass psychology of Fascism. New York, United States: Orgone Institute Press.

SALAMON, Gayle. (2010). Assuming a body: transgenderism and the rhetorics of materiality. New York: Columbia University Press.

WITTIG, Monique. (1990). "Homo Sum". Feminist issues, vol. 1, 1990, pp. 1-11.

XAVIER, Anna K.; ROSATO, Cassia M. (2016). "Mulheres e direitos: saúde sexual e reprodutiva a partir das Conferências da ONU”. Revista Ártemis, vol. 21, nº 1, pp. 116-130.

Recebido em: 05/04/2017.

Aceito: 03/05/2017. 